\title{
A fine-grained bird Atlas as tool for spatial monitoring: a case study from a remnant wetland during the breeding period (Torre Flavia, central Italy)
}

\author{
Corrado Battisti ${ }^{1, *}$, Giuseppe Dodaro ${ }^{2}$, Mario Vannuccini ${ }^{3}$
}

\begin{abstract}
During the 2019 breeding period we carried out a bird atlas for a small coastal natural reserve (Torre Flavia wetland, Special Protection Area IT6030020, central Italy), comparing quantitative data of spatial occurrences with records from an analogous study carried out in 2005. From 2005 to 2019 some water-related species increased their frequency of occurrence (Fulica atra, significantly). Among the reed and rush-bed species, Acrocephalus scirpaceus spatially increased and Cisticola juncidis decreased significantly. Among ecotonal, synanthropic and open habitat species, we registered a significant increase of Chloris chloris. A decreasing trend of Passer italiae, Saxicola torquatus, Emberiza calandra, although not significant, may be probably linked to regional or continental factors. Both causes at local (reedbed expansion, rushbed reduction, water-level management) and at larger scale (decline in their continental range) can explain the observed changes in spatial occurrences during this medium-long temporal range. Local atlases can be quick tools useful to drive management strategies in remnant wetlands.
\end{abstract}

Key words: local atlases, changes in spatial occurrences, reed beds, rush beds, management strategies, local vs. large scale factors, long term monitoring.

Riassunto - L'Atlante ornitologico come strumento per il monitoraggio della distribuzione spaziale delle specie durante il periodo riproduttivo: un caso studio applicato a un'area umida residuale mediterranea (Torre Flavia, Italia Centrale).

L'Atlante ornitologico del Monumento naturale Palude di Torre Flavia, una piccola zona umida costiera residuale (ZPS IT6030020; Lazio, Italia centrale), illustra i dati relativi alla presenza e alla distribuzione spaziale delle specie ornitiche durante il periodo riproduttivo (aprile - giugno) del 2019, riportando anche una comparazione con dati analoghi raccolti nello stesso arco temporale nel 2005.

\footnotetext{
1 'Torre Flavia' LTER (Long Term Ecological Research) Station, Protected areas - Regional park Service, Città Metropolitana di Roma Capitale, viale G. Ribotta 41, 00144 Roma, Italia.

${ }^{2}$ Sustainable Development Foundation, via Garigliano 61a, 00198 Roma, Italia.

E-mail: dodaro@susdef.it

Eureco Studio Associato, Verde \& Città, Natura \& Territorio, Via Poggiolo e Tarole 8/A, 51100 Pistoia (PT), Italia.

E-mail: mario.vannuccini@studioeureco.com
}

*Correspondingauthor:c.battisti@cittametropolitanaroma.gov.it (C) 2020 Corrado Battisti, Giuseppe Dodaro, Mario Vannuccini

Received: 26 March 2020

Accepted for publication: 20 May 2020

Online publication: 26 October 2020
I risultati evidenziano alcune differenze, in qualche caso anche molto marcate. Si registra un generale incremento delle specie più strettamente legate agli ambienti umidi, particolarmente rilevante per quanto concerne Fulica atra. Relativamente alle specie tipiche dei canneti e delle praterie alofile a dominanza di giunchi, aumentano le aree in cui è presente Acrocephalus scirpaceus mentre diminuiscono sensibilmente quelle in cui si rinviene Cisticola juncidis.

Tra le specie caratteristiche delle aree ecotonali e sinantropiche si riscontra una maggiore frequenza di Chloris chloris. La presenza ridotta - sebbene in maniera non particolarmente accentuata - di Passer italiae, Saxicola torquatus ed Emberiza calandra è presumibilmente da mettere in relazione con dinamiche di livello regionale e continentale.

I cambiamenti nella distribuzione spaziale delle specie - osservati in questo arco temporale di media lunghezza - dipendono dunque sia da fattori di area vasta (alcuni degli Uccelli contattati hanno popolazioni in declino in tutta Europa) che da elementi di carattere ambientale riferiti invece in maniera specifica a questa piccola area protetta. Tra quelli più incisivi si evidenziano l'applicazione di un nuovo regime di gestione dei livelli idrici - con una disponibilità di risorsa maggiore e più continua - l'espansione del canneto e la contemporanea riduzione della vegetazione alofila e sub-alofila.

Gli atlanti locali sono strumenti in grado di fornire concreti benefici per il management di piccole aree protette. La rappresentazione spaziale della distribuzione delle specie sul territorio - soprattutto quando ripetuta a intervalli regolari - consente di individuare le zone sensibili e quelle di maggiore interesse ecologico, così come facilita l'interpretazione dei processi ecologici in corso, rappresentando così un supporto di grande utilità per una pianificazione adeguata di interventi e strategie di gestione.

Parole chiave: atlanti locali, modifiche nella distribuzione spaziale, canneti, giuncheti, strategie di gestione, fattori locali vs fattori di scala vasta, monitoraggi

\section{INTRODUCTION}

Wetlands provide many ecosystem services (Okruszko et al., 2011; Mitsch et al., 2015) and play a major role in maintaining well-being and economic activities (Mediterranean Wetlands Observatory, 2012, 2018). This role is particularly relevant in the Mediterranean basin, where natural and human-made wetlands cover ca. 0.15-0.22 million $\mathrm{km}^{2}-$ about $1.1-1.5 \%$ of wetland area globally (Davidson et al., 2018) - and have a recognized importance for the protection of biodiversity on a global scale (Cuttelod et al., 2008; Malcolm et al., 2006). Nevertheless, wetlands are the most threatened ecosystems throughout this area and their surface continues to decline very rapidly (Finlayson \& Spiers, 1999; Perennou et al., 2012; 
Mediterranean Wetlands Observatory, 2018), with effects on biodiversity, although with significant differences between different areas and groups of species (Fraixedas et al., 2019; Galewski et al., 2011; Green et al., 2002), also due to the increase in some pressures linked to the climate change (Cramer et al., 2018). In this scenario it is necessary and urgent on the one hand to use the knowledge acquired regarding the state of conservation and the most effective wetland restoration techniques (Zalidis et al., 1999; Ortega et al., 2004), on the other to improve knowledge regarding the conservation status of species and habitats at local scale, to create management models capable of responding adequately to new environmental conditions and improving the conservation of biodiversity.

Birds are good indicators of the health status of wetlands (Robledano et al., 2010; Hoffmann et al., 1996) and monitoring the trend of species populations provides useful indications regarding the changes taking place and the strategies to be adopted (Galewski \& Devictor, 2016).

Small Mediterranean wetlands play an important role as stepping stones for migratory birds and as a reproductive habitat for breeding species, also of conservation concern (Benassi et al., 2009). Quantitative surveys on species and communities occurring in these sites (e.g. fine-grained spatial distribution trends obtained from atlases) can also be important for their medium-long term monitoring and management (Sutherland, 2006).

In this work, we characterized the local scale distribution of breeding birds in a small coastal wetland in central Italy. The quantitative data of spatial occurrences were compared with those obtained with the same method carried out in 2005, obtaining first information on distributional changes at local scale of breeding species related to these wet and ecotonal environments.

\section{MATERIALS AND METHODS}

\section{Study area}

The study area is included in the "Palude di Torre Flavia" natural Monument (central Italy; $41^{\circ} 58^{\prime} \mathrm{N}$; $12^{\circ} 03^{\prime} \mathrm{E}$; Fig. 1), a small protected wetland (40 ha) on the Tyrrhenian coast (Special Protection Area IT6030020, according to the EC Directive on the Conservation of Wild Bird 2009/147/EC), remnant of a larger wetland drained and transformed by land reclamation in the last Century and now embedded in an agricultural and urbanized matrix (Battisti, 2006; Battisti et al., 2006). At local scale, it shows a semi-natural heterogeneity with Phragmites australis reed-beds, channels used for fish farming (Anguilla anguilla and three species of mullets: Mugil cephalus, Liza saliens, Liza ramada), flooded salt meadows with Carex hirta, Juncus acutus and Cyperaceae (corresponding to 1410 Mediterranean salt meadows (Juncetalia maritimi) habitat type according EC "Habitat" Directive 92/43/EC), dune and backdune areas (Acosta et al., 2007). Hereafter, we refer to "open habitat" to comprise flooded meadows, edge areas, dunes and backdunes. Climate is xeric-mesoMediterranean (Tomaselli et al., 1973; Blasi \& Michetti, 2005). The water in the wetland area is mainly of mete-

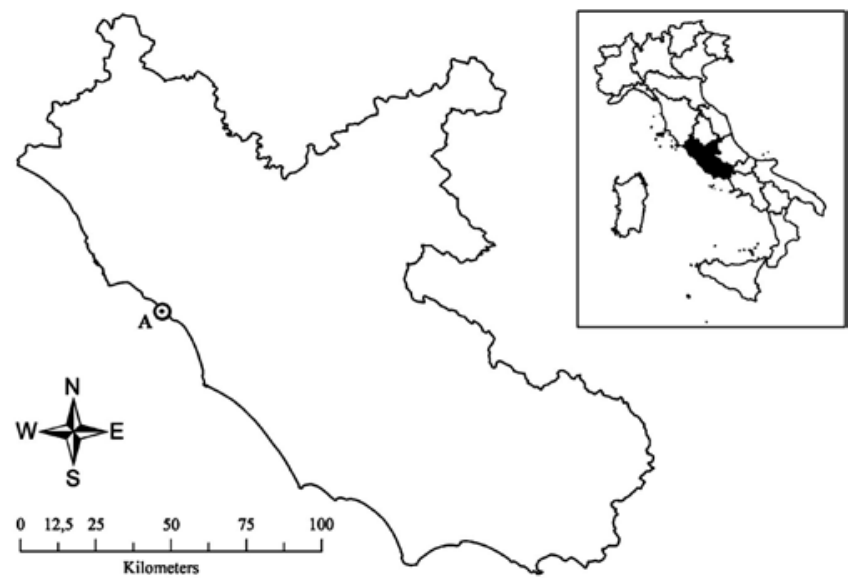

Fig. 1 - Geographic localization of the study area (Latium, central Italy). Location of the coastal study site (A). On the right: geographic location within Italy. / Localizzazione del sito di studio (A) all'interno dell'area vasta (Lazio, Italia Centrale). Sulla destra: localizzazione rispetto al territorio nazionale (Italia).

oric and sea-storm origin and flow from surrounding areas is scarce. Depth is variable in time, and no water is present from July to October (Battisti, 2006). Water stress is one of the main local direct threats known for Torre Flavia wetland (Battisti et al., 2008). This threat has been actively mitigated from the management Agency (Battisti et al., 2020a).

\section{Protocol}

We obtained a local atlas (Bibby et al., 2000; Sutherland, 2006) defining a squared grid that was superimposed on the entire study area during the breeding period (and some immediately adjacent sites). This grid was made up of 64 survey units (SU), each $100 \times 100$ m wide (based on the Regional Technical Map scale 1: 10,000; Regione Lazio, 1990).

In the spring 2019 (from 2 April to 6 June), coinciding with the local breeding season, we randomly moved through the sector of each SU twice (two sessions/SU) during each seasonal period (the first in March and April, the second in May and June). In each of the two sessions, a route was randomly carried out, as representative as possible of the entire SU, keeping the detection time constant (5 minutes/SU/session).

During each sampling, a direct contact (observation of individuals) and indirect contact (recognition through singing, voice and other sound emissions relating to species presumably nesting in the area), were noted on a specially prepared detection sheet, thus obtaining a data of presence for each detection unit (occurrence/SU). For the purpose of graphically returning the occurrences in the Atlas, we considered a species as occurring in a SU if at least a direct or indirect contact of the species was obtained in at least one session. We have accumulated the occurrence data obtained from the two sessions for each SU. The species in high flight $(>25 \mathrm{~m})$ were not considered.

In total 128 sessions were completed, corresponding to about 640 minutes of sampling research effort. No abundance data for individual species were obtained. 
Subsequently, a binary / species matrix was initially built, where 1 indicated the certain presence of the species (cumulated over two sessions), while 0 indicated the probable absence within each SU. For each species, a local scale distribution map was built, also obtaining a map of overall richness. For each species we obtained the number of SU occupied $\left(\mathrm{N}_{\mathrm{SU}}\right)$ and the percentage frequency of sampling units ( $\mathrm{fr}_{\mathrm{SU}}$ i.e. n. SU/64). The percentage frequency (or frequency of incidence: Magurran, 2004) provides information on the degree of local distribution of the species in the study area. The relative frequency of occurrence of the species was also calculated (fr, i.e. the ratio between the number of SU occupied by a species and the total number of occurrences; $\mathrm{fr}_{\text {occ }}$ ). This frequency data was used to obtain preliminary information on the local distribution of the breeding bird community in the study area. Since in this observational study, time effort for each SU is limited, we do not have certain breeding evidence for each species in each SU. Consequently, this atlas reports only information of the occurrence of species in each SU during the breeding period (i.e. habitat use during breeding period), without implication on the confirmed nesting.

On this basis, a map of overall species richness for each SU was also obtained. The single-species maps were created with QGIS software and geo-referenced based on AGEA 2014 ortho-photo (Datum Roma 1940, Gauss Boaga projection, east time zone).

The average value of $\mathrm{N}_{\mathrm{SU}}$ (and standard deviation) was calculated obtaining a mean species richness value. Finally, from the data of the frequency of occurrence, we obtained a spatially-referred Shannon-Wienerdiversityindex(ShannonWeaver; Magurran, 2004). The results were compared with similar data obtained in 2005 when we carried out a similar atlas using the same methodology (Malavasi et al., 2006).

In order to compare the values obtained in 2019 with those of 2005, we applied the Mann-Whitney U test applied to mean species richness; $\chi^{2}$ test to compare the frequencies of occurrence at single species level. Alpha was set at 0.05 level. The SPSS 13.0 software (SPSS Inc. 2003 ) was used. Reference was made to the nomenclature and the new systematic order (CISO, 2019).

\section{RESULTS}

In 2019, 221 occurrences of 27 species were obtained compared to the 243 occurrences and 24 species in 2005. Gallinula chloropus, Fulica atra, Cisticola juncidis, Acrocephalus scirpaceus, Cettia cetti, Turdus merula, Passer italiae, Chloris chloris were dominant ( $\mathrm{fr}>0.05)$. Maps of single species are in Fig. 2. Mean species richness was $3.45( \pm 2.67)$ species/SU in 2019 vs $4.92( \pm 2.31)$ in 2005. Mean species richness decreased significantly from 2005 to 2019 ( $Z$ = $-2.722, p=0.006$; Mann Whitney U test). Shannon-Wiener diversity index was $\mathrm{H}^{\prime}=2.74$ in 2019 and $\mathrm{H}^{\prime}=2.76$ in 2005 .

The SU with highest richness are located in the edge of the study area (Fig. 3).

The comparison between the years showed an increase in the distribution at the local scale of some water-related species (Anas platyrhynchos, Gallinula chloropus, Fulica atra, the latter significantly; Tab. 1). Among the reed-bed related species, Acrocephalus scirpaceus showed a significant incre- ase in its frequency of occurrence, while Cisticola juncidis showed a significant reduction. Ecotonal, synanthropic and open habitat species showed contrasting trends: among these only Chloris chloris recorded a significant increase. Marked decreases, although not significant, were recorded for Passer italiae, Saxicola torquatus, and Emberiza calandra (Tab. 1).

\section{DISCUSSION AND CONCLUSIONS}

The data obtained show an increase in the local scale distribution of water-related and reedbeds-related species and a decrease in a focal rushbeds species (Cisticola juncidis). This can be due to (i) the increase in reed bed extension (and consequent reduction of surrounding rushbeds), and (ii) to an effective water level management (promoted by Park Agency; Battisti et al., 2020a) during the last years. These environmental and management factors are important for small wetlands since many species linked to these habitats are area- or fragmentation-sensitive (Benassi et al., 2009): therefore the increase in habitat size (reed beds) and quality (effective water level management) could make more suitable these remnant ecosystems for reed bed specialists (as Acrocephalus spp.) and water-related species (as ducks and rails). These localscale distributional data (spatial occurrences) corroborate the findings for the same area using a different method (mapping) which recorded an increase in density in the breeding pairs of the reed beds species and a reduction in the rush beds species (Battisti et al., 2020b).

However, beyond local factors, also causes on a larger scale could explain the decline of some species related to ecotonal, synathropic and open environments (e.g. Saxicola torquatus: Sanderson et al., 2006; Passer sp.: De Laet \& Summers-Smith, 2007; Emberiza calandra: Massa \& La Mantia, 2010; Cisticola juncidis: Campedelli et al., 2009; all species showing decreasing or large temporal fluctuations on a regional/continental scale). The decline of these species can explain also the significant decrease in mean species richness and the consequently apparently reduction in the Shannon-Wiener index from 2005 to 2019.

The approach using in this study has some weakness. First, a disadvantage with atlas grids of any type is that boundaries rarely match those of habitats, making them unsuitable for some types of ecological studies (Donald \& Fuller, 1998). Secondly, we carried out a strict comparison between two years without an analysis ranging along all the period 2005-2019: consequently, fluctuations in populations due to causes related to wintering/migration areas, predators/parasites and so on have not considered. A part this weaknesses, this study also highlights some usefulness of this quick methodological tool (i.e. requiring a relatively low research effort) on a local scale to highlight responses in terms of spatial occurrences by species in relation to environmental changes, so as to provide for appropriate management measures. In our case, the historical comparison has made it possible to trace environmental changes on a local scale (increase in size and ageing of reed beds, rush bed reduction, reduction in water stress) which will enable management actions to be prepared (e.g. reed bed management by mowing, habitat restoration for rush beds, water level management). 
Fig. 2 - Local distribution maps at local scale of breeding bird species in Torre Flavia wetland (Latium, central Italy; 2019). Black points: occurrences; grey points: contacts outside the sampling methods (not included in the analyses). / Mappe di distribuzione alla scala locale delle specie nidificanti nella palude di Torre Flavia (Lazio, Italia centrale; 2019). Pallini neri: presenze; pallini grigi: contatti al di fuori dei tempi di campionamento (non compresi nelle analisi statistiche).

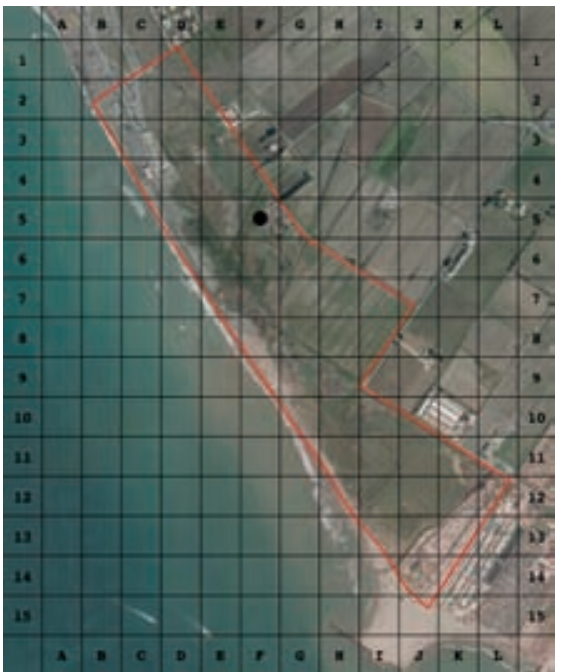

Coturnix coturnix

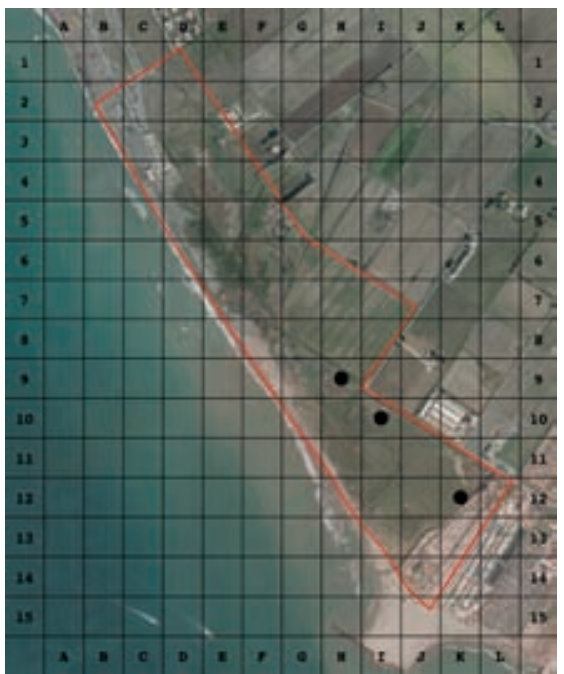

Tachybaptus ruficollis

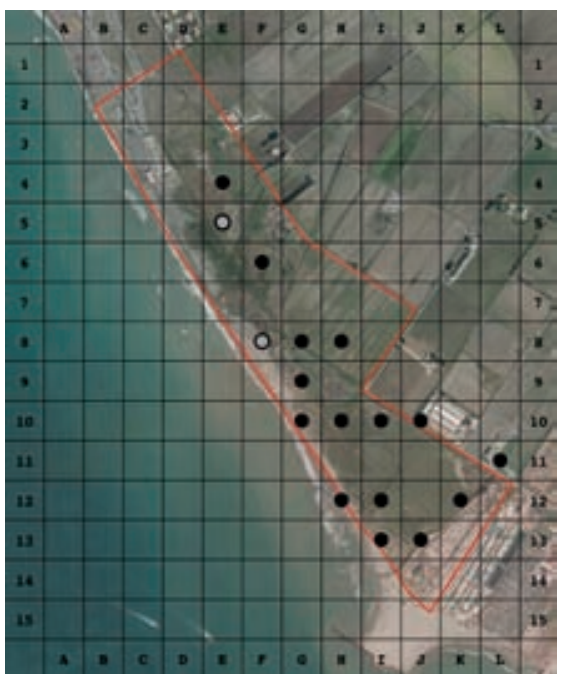

Gallinula chloropus

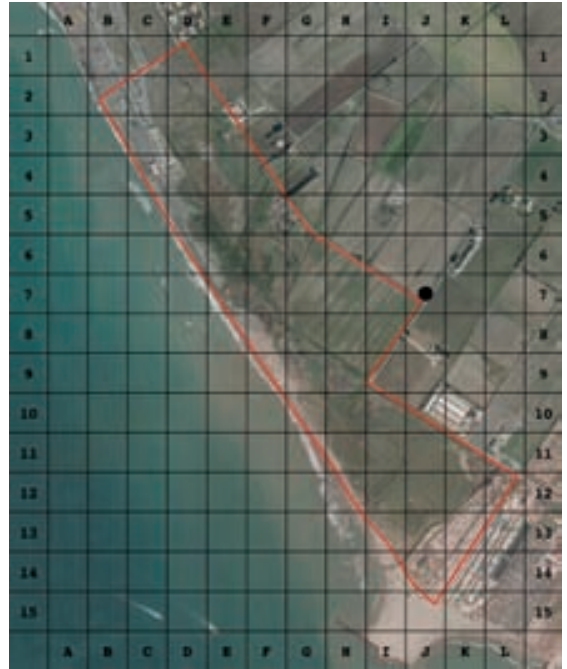

Phasianus colchicus

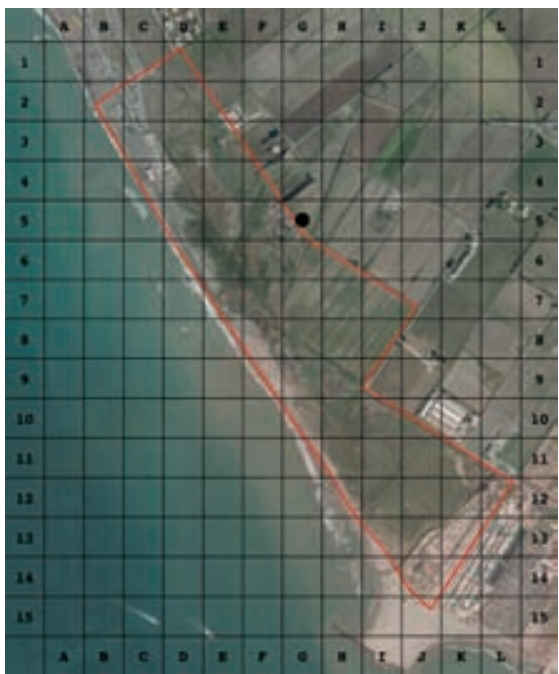

Columba liva forma domestica

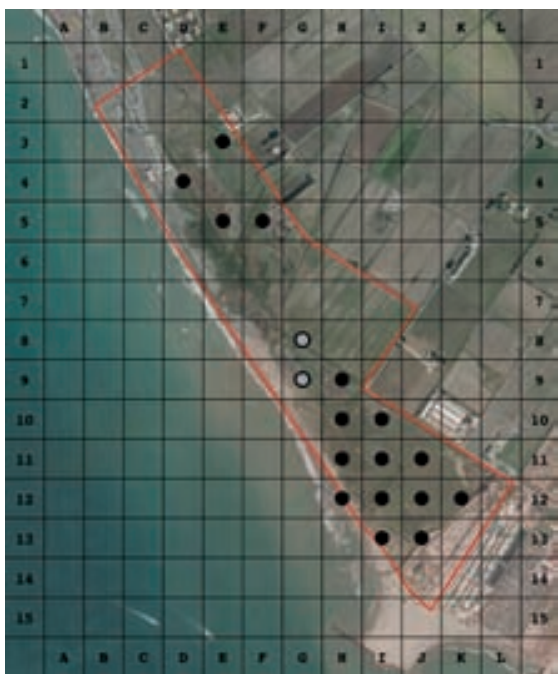

Fulica atra

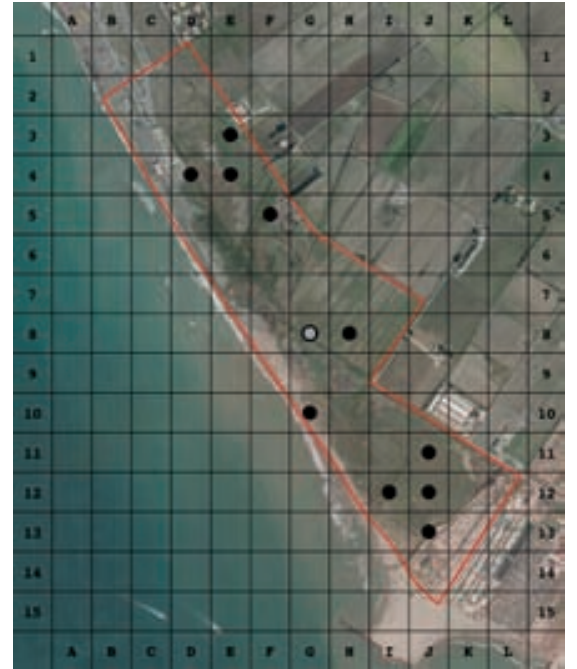

Anas platyrhynchos

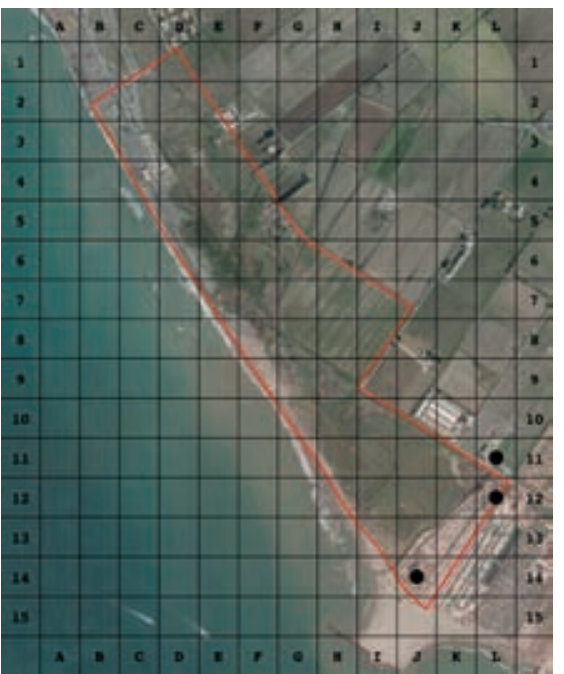

Streptopelia decaocto

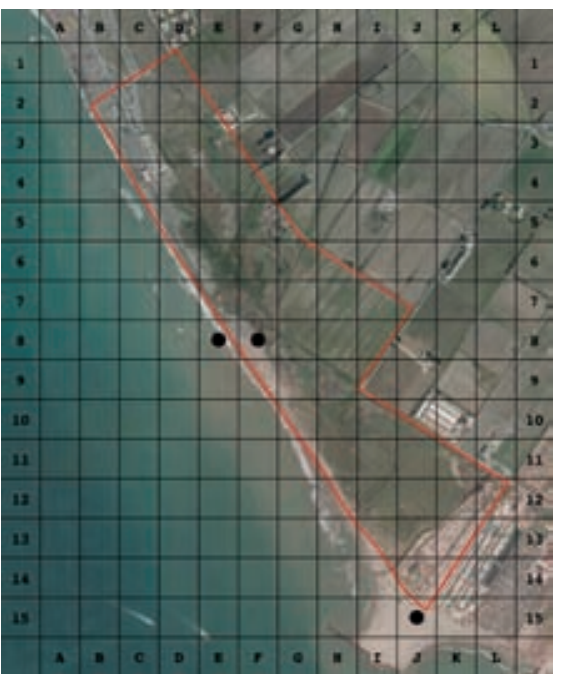

Charadrius dubius 


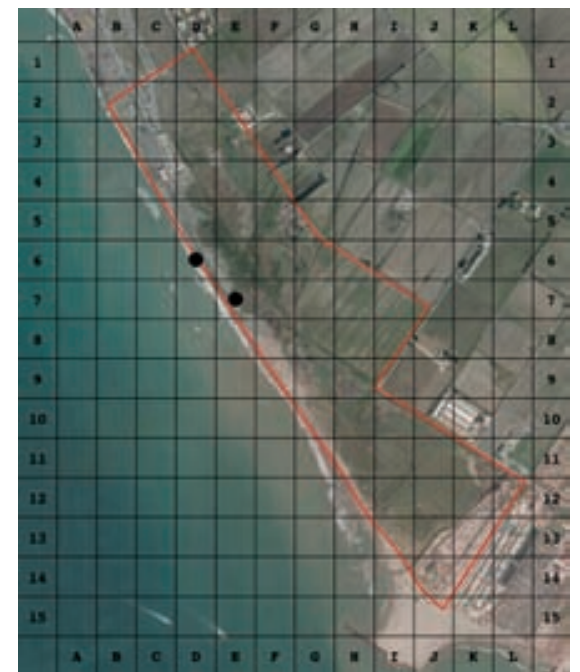

Charadrius alexandrinus

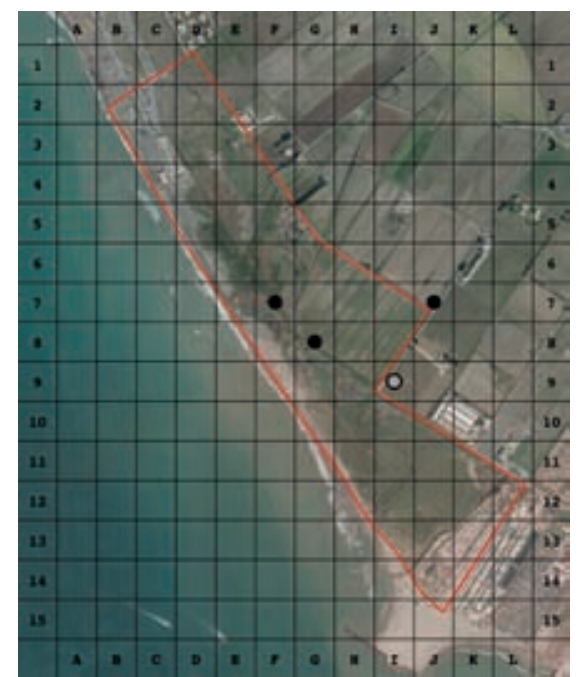

Parus major

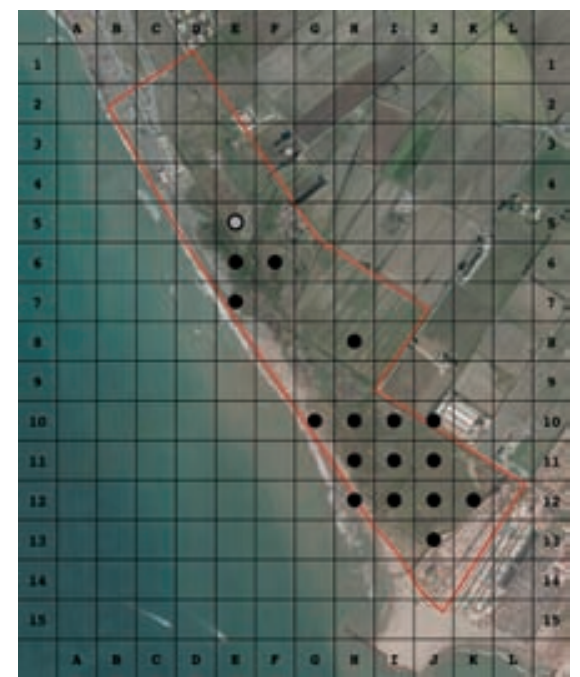

Acrocephalus scirpaceus

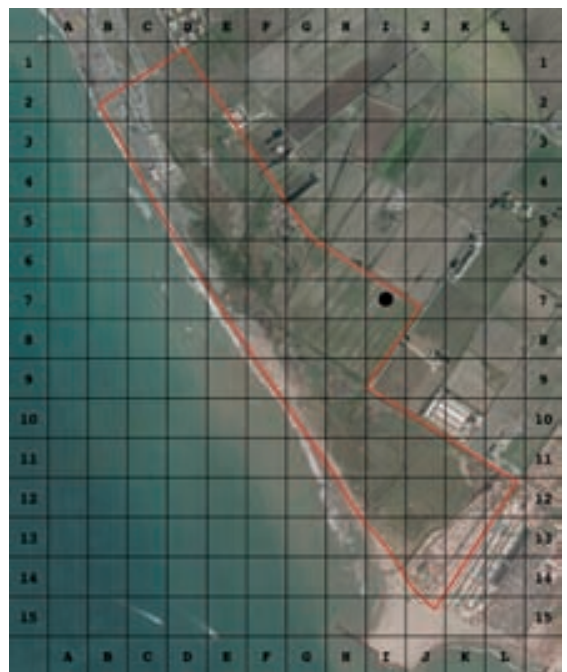

Lanius collurio

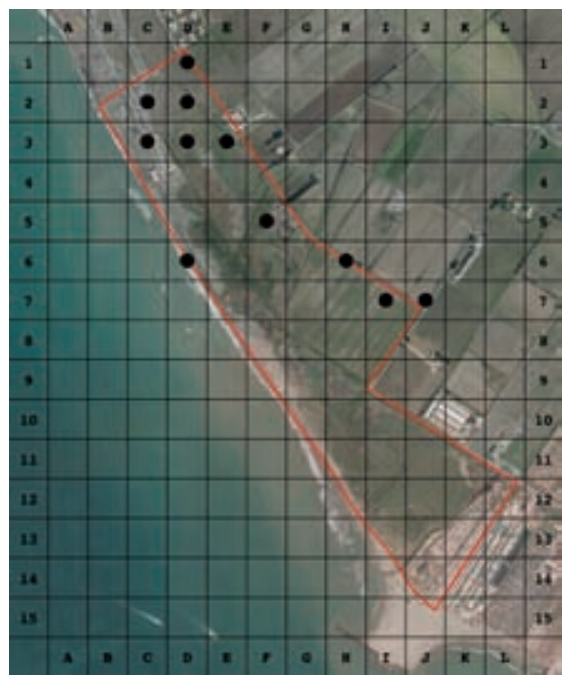

Galerida cristata

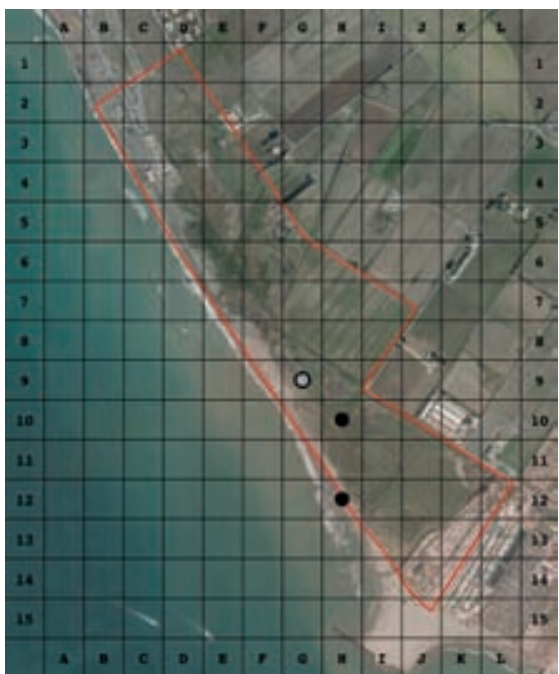

Acrocephalus arundinaceus

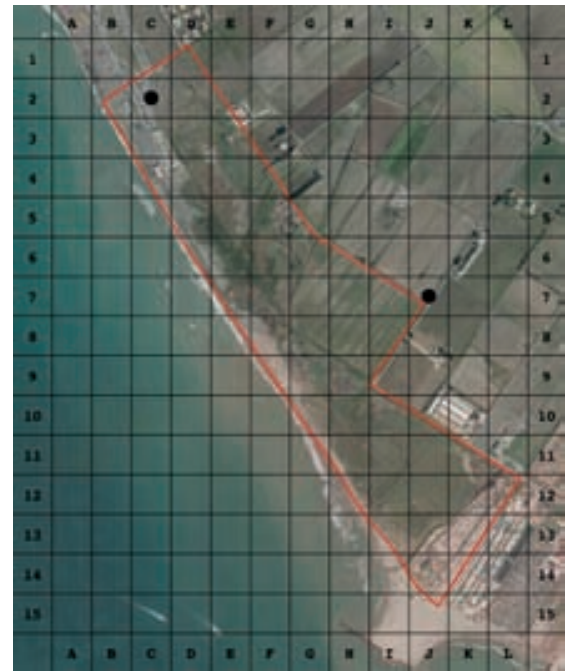

Pica pica

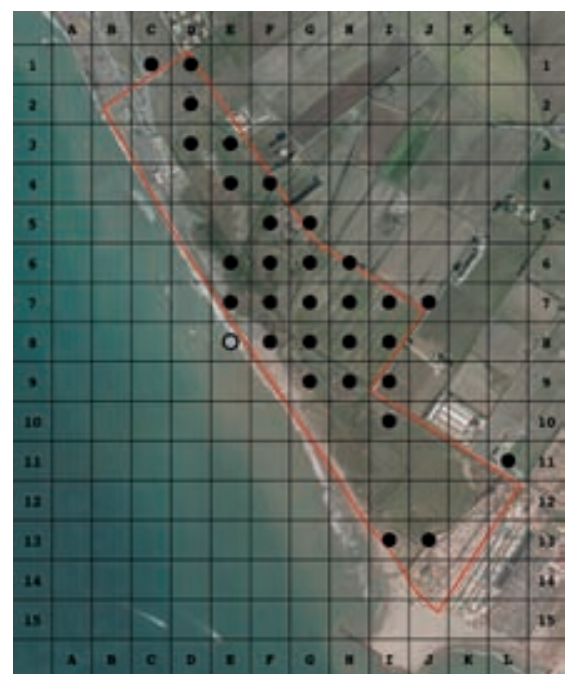

Cisticola juncidis

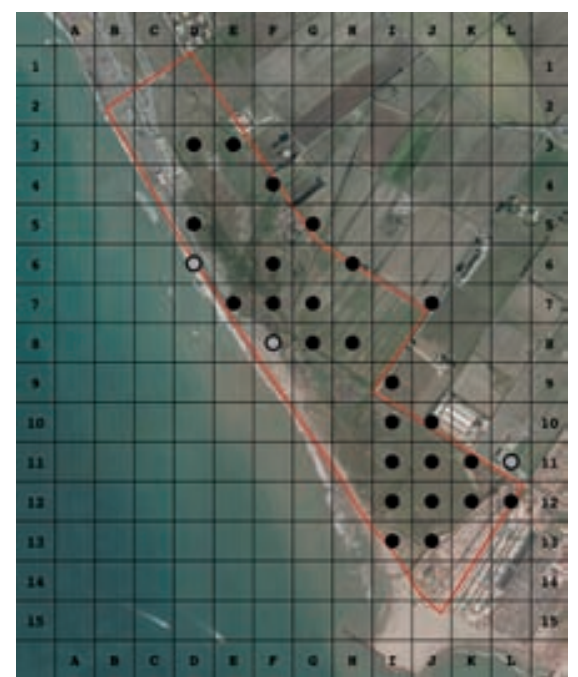

Cettia cetti 


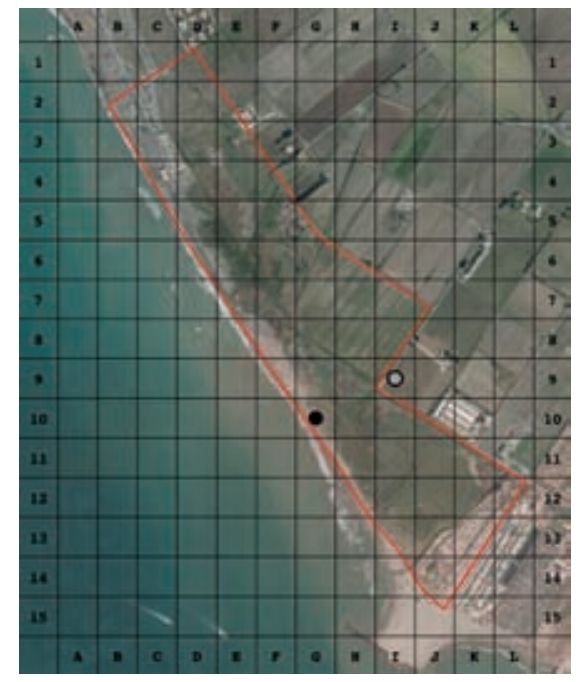

Sylvia melanocephala

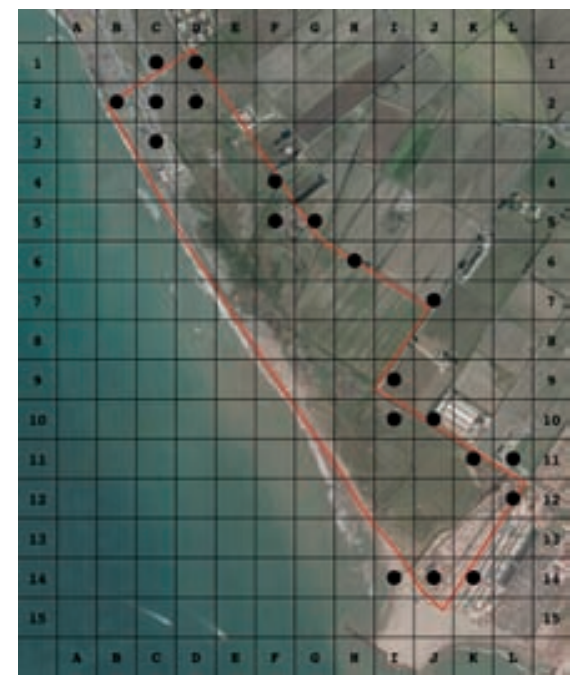

Passer italiae

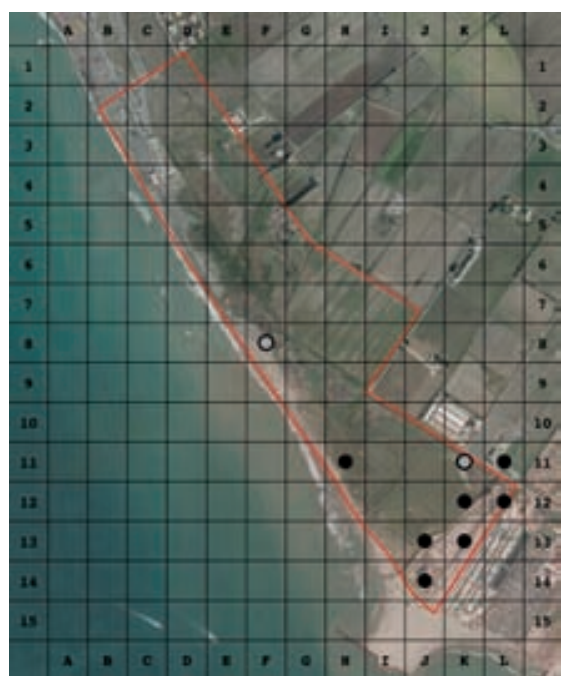

Carduelis carduelis

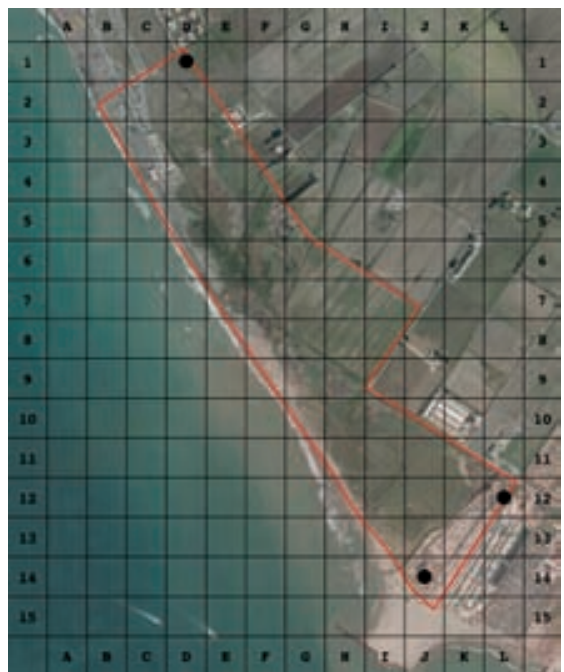

Sturnus vulgaris

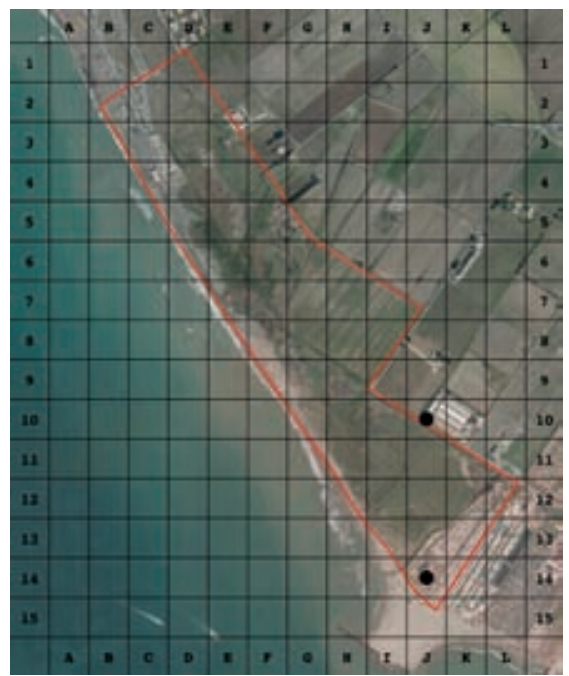

Motacilla alba

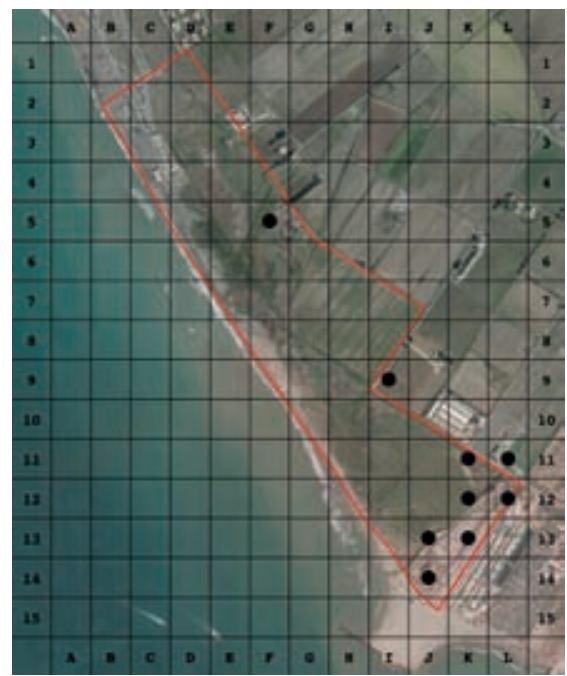

Serinus serinus

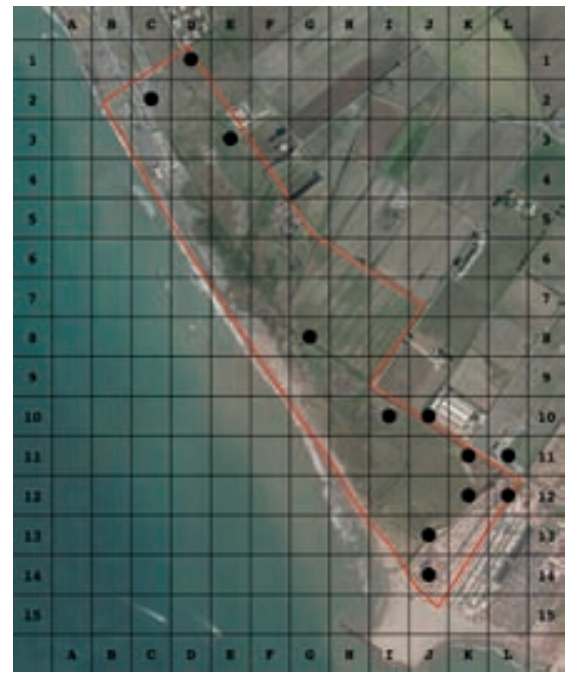

Turdus merula

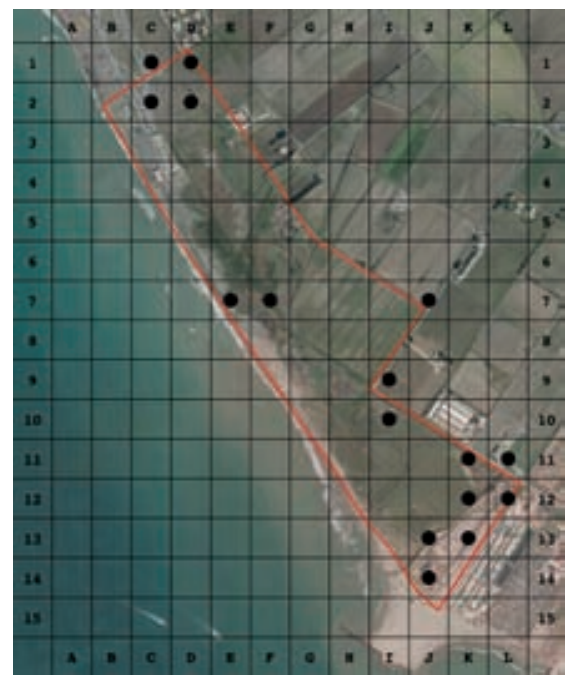

Chloris chloris

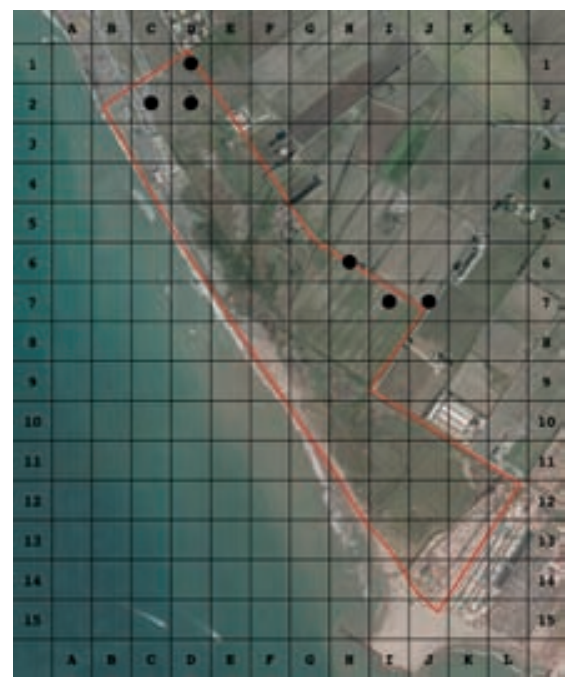

Emberiza calandra 


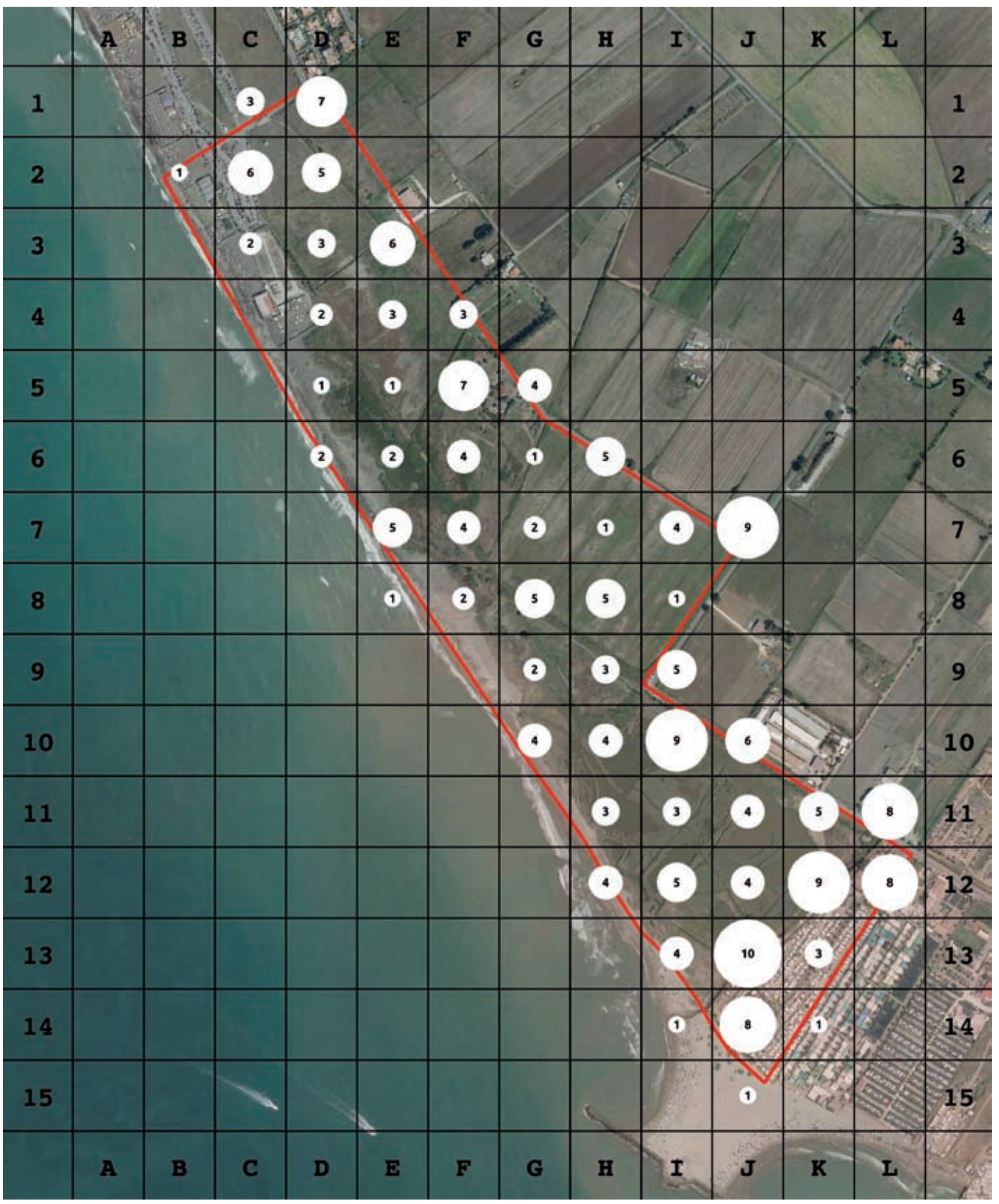

Fig. 3 - Map of species richness of breeding birds in the Torre Flavia wetland (2019). Number of species have been reported inside the white circles. / Mappa della ricchezza di specie di Uccelli nidificanti nella palude di Torre Flavia (2019). All'interno dei pallini bianchi è riportato il numero di specie nidificanti per ciascuna UR. 
Tab. 1 - Spatial occurrences and relative frequencies (on SU and in total of occurrences) of breeding bird species in the Torre Flavia wetland (central Italy). Data from 2005: Malavasi et al. (2006). Comparisons between frequencies has been performed with the $\chi^{2}$ test (see Methods). / Presenze spaziali e relative frequenze (su SU e sul totale delle occorrenze) di specie di uccelli nidificanti nell'area umida di Torre Flavia (Italia centrale). Dati del 2005: Malavasi et al. (2006). I confronti tra le frequenze sono stati eseguiti con il test $\chi^{2}$ (vedi Metodi).

\begin{tabular}{|c|c|c|c|c|c|c|c|c|}
\hline & \multicolumn{3}{|c|}{2005} & \multicolumn{3}{|c|}{2019} & \multirow[b]{2}{*}{$\chi^{2}$} & \multirow[b]{2}{*}{$\mathrm{P}$} \\
\hline & $\mathrm{N}_{\mathrm{SU}}$ & $\mathrm{Fr}_{\text {occ }}$ & $\mathrm{Fr}_{\mathrm{SU}}$ & $\mathrm{N}_{\mathrm{SU}}$ & $\mathrm{Fr}_{\text {occ }}$ & $\mathrm{Fr}_{\mathrm{SU}}$ & & \\
\hline Coturnix coturnix & & & & 1 & 0.005 & 0.016 & & \\
\hline Phasianus colchicus & & & & 1 & 0.005 & 0.016 & & \\
\hline Anas platyrhynchos & 8 & 0.033 & 0.119 & 10 & 0.045 & 0.16 & 0.199 & 0.656 \\
\hline Tachybaptus ruficollis & & & & 3 & 0.014 & 0.047 & & \\
\hline Columba livia f. domestica & 8 & 0.033 & 0.119 & 1 & 0.005 & 0.016 & & \\
\hline Streptopelia decaocto & 3 & 0.012 & 0.045 & 3 & 0.014 & 0.047 & & \\
\hline Gallinula chloropus & 7 & 0.029 & 0.104 & 15 & 0.068 & 0.234 & 3.094 & 0.079 \\
\hline Fulica atra & 6 & 0.025 & 0.09 & 16 & 0.072 & 0.25 & 4.824 & $0.028 *$ \\
\hline Ixobrychus minutus & 2 & 0.008 & 0.03 & & & & & \\
\hline Charadrius dubius & & & & 3 & 0.014 & 0.047 & & \\
\hline Charadrius alexandrinus & & & & 2 & 0.009 & 0.031 & & \\
\hline Lanius collurio & & & & 1 & 0.005 & 0.016 & & \\
\hline Pica pica & 4 & 0.016 & 0.06 & 2 & 0.009 & 0.031 & & \\
\hline Parus major & & & & 3 & 0.014 & 0.047 & & \\
\hline Alauda arvensis & 5 & 0.021 & 0.075 & & & & & \\
\hline Galerida cristata & 15 & 0.062 & 0.224 & 11 & 0.05 & 0.172 & 0.128 & 0.721 \\
\hline Cisticola juncidis & 45 & 0.185 & 0.672 & 30 & 0.136 & 0.469 & 18.42 & $0.001 * *$ \\
\hline Acrocephalus scirpaceus & 6 & 0.025 & 0.09 & 16 & 0.072 & 0.25 & 60.58 & $0.001 * *$ \\
\hline Acrocephalus arundinaceus & 1 & 0.004 & 0.015 & 2 & 0.009 & 0.031 & & \\
\hline Cettia cetti & 23 & 0.095 & 0.343 & 25 & 0.113 & 0.391 & 0.25 & 0.617 \\
\hline Sylvia melanocephala & 5 & 0.021 & 0.075 & 1 & 0.005 & 0.016 & & \\
\hline Sturnus vulgaris & 8 & 0.033 & 0.119 & 3 & 0.014 & 0.047 & & \\
\hline Turdus merula & 19 & 0.078 & 0.284 & 12 & 0.054 & 0.188 & 0.711 & 0.399 \\
\hline Saxicola torquatus & 8 & 0.033 & 0.119 & & & & & \\
\hline Passer italiae & 37 & 0.152 & 0.552 & 20 & 0.09 & 0.313 & 3.36 & 0.067 \\
\hline Passer montanus & 3 & 0.012 & 0.045 & & & & & \\
\hline Motacilla alba & 1 & 0.004 & 0.015 & 2 & 0.009 & 0.031 & & \\
\hline Chloris chloris & 4 & 0.016 & 0.06 & 16 & 0.072 & 0.25 & 7.476 & $0.006 * *$ \\
\hline Carduelis carduelis & 8 & 0.033 & 0.119 & 7 & 0.032 & 0.109 & 0.035 & 0.852 \\
\hline Serinus serinus & 6 & 0.025 & 0.09 & 9 & 0.041 & 0.141 & 0.508 & 0.476 \\
\hline Emberiza calandra & 11 & 0.045 & 0.164 & 6 & 0.027 & 0.094 & 0.624 & 0.429 \\
\hline Total & 243 & 1 & & 221 & 1 & 1 & & \\
\hline
\end{tabular}




\section{Acknowledgments}

We wish to thanks the operators of the Torre Flavia Protected area (E. De Angelis, C. Galimberti, N. Trucchia; Città Metropolitana di Roma Capitale) which support us during the field sampling. An anonymous reviewer and the Editor provided useful comments and suggestions that improved a first draft of the manuscript.

$\mathrm{CB}$ and GD defined the atlas design, carried out the field sampling and performed the statistical analyses, MV developed the species map. All the autors discussed the results and commented on the manuscript.

\section{REFERENCES}

Acosta A., Ercole S., Stanisci A., Pillar V. D. P. \& Blasi C., 2007 - Coastal vegetation zonation and dune morphology in some Mediterranean ecosystems. Journal of Coastal Research, 23: 1518-1524.

Battisti C. (ed.), 2006 - Biodiversità, gestione, conservazione di un'area umida del litorale tirrenico: la Palude di Torre Flavia. Provincia di Roma, Gangemi editore, Roma.

Battisti C., Aglitti C., Sorace A. \& Trotta M., 2006 - Water level and its effect on the breeding bird community in a remnant wetland in Central Italy. Ekologia (Bratislava), 25: 252-263.

Battisti C., Luiselli L., Pantano D. \& Teofili C., $2008-$ Threats analysis approach applied to a Mediterranean remnant wetland: Is the assessment of human-induced threats related into different level of expertise of respondents? Biodiversity and Conservation, 16: 15291542.

Battisti C., De Angelis E., Galimberti C., Trucchia N., 2020a - La gestione operativa di un ecosistema: la Palude di Torre Flavia. Un manuale per studenti e volontari. Città Metropolitana di Roma Capitale, Roma.

Battisti C., Grosso G., Ioni S., Zullo F. \& Cerfolli F., $2020 \mathrm{~b}$ - Response of specialized birds to reedbed aging in a Mediterranean wetland: Significant changes in bird biomass after two decades. Israel Journal of Ecology and Evolution. <https://doi. org/10.1163/22244662-bja10007>

Benassi G., Battisti C., Luiselli L. \& Boitani, L., 2009 Area-sensitivity of three reed bed bird species breeding in Mediterranean marshland fragments. Wetlands Ecology and Management, 17: 555-564.

Bibby C. J., Burgess N. D., Hill D. A. \& Mustoe S., $2000-$ Bird census techniques. Elsevier, London.

Blasi C. \& Michetti L., 2005 - Biodiversità e Clima. In: Stato della biodiversità in Italia. Contributo alla strategia nazionale per la biodiversità. Blasi C., Boitani L., La Posta S., Manes F. \& Marchetti M. (eds.). Ministero dell'Ambiente e della Tutela del territorio. F.lli Palombi editori, Roma.

Campedelli T., Tellini Florenzano G., Sorace A. Fornasari L., Londi G. \& Mini L., 2009 - Species selection to develop an Italian farmland bird index. Avocetta, 33: 87-91.

CISO, 2019 - Checklist CISO-COI degli uccelli italiani. Available: <http://ciso-coi.it/commissione-ornitologica-italiana/checklist-e-red-list $>$
Cramer W., Guiot J., Fader M., Garrabou J., Gattuso J. P., Iglesias A., Lange M., Lionello P., Llasat M. C., Paz S., Penuelas J., Snoussi M., Toreti A., Tsimplis M. \& Xoplaki E., 2018 - Climate change and interconnected risks to sustainable development in the Mediterranean. Nature Climate Change, 8: 972-980.

Cuttelod A., García N., Abdul Malak D., Temple H., Katariya V., 2008 - The Mediterranean: a biodiversity hotspot under threat. In: Wildlife in a changing world. An analysis of the 2008 IUCN Red List of Threatened Species. Vié J-C., Hilton-Taylor C. \& Stuart S. N. (eds.). IUCN, Gland: 89-101.

Davidson N. C., Fluet-Chouinard E. \& Finlayson C. M., 2018 - Global extent and distribution of wetlands: trends and issues. Marine and Freshwater Research, 69: 620-627.

De Laet J. \& Summers-Smith J. D., 2007 - The status of the urban house sparrow Passer domesticus in northwestern Europe: a review. Journal of Ornithology, 148: 275-278.

Donald P. F. \& Fuller R. J., 1998 - Ornithological atlas data: a review of uses and limitations. Bird Study, 45: 129-145.

Finlayson C. M. \& Spiers A. G., 1999 - Global review of wetland resources and priorities for wetland inventory. Supervising Scientist Report, 144. / Wetlands International Publication 53, Supervising Scientist, Canberra.

Fraixedas S., Galewski T., Ribeiro-Lopes S., Loh J., Blondel J., Fontès H., Grillas P., Lambret P., Nicolas D., Olivier A. \& Geijzendorffer I. R., 2019 - Estimating biodiversity changes in the Camargue wetlands. An expert knowledge approach. PLoS One, 14: e0224235.

Galewski T. \& Devictor V., 2016 - When common birds became rare: Historical records shed light on long-term responses of bird communities to global change in the largest wetland of France. PloSOne, 11: e0165542.

Galewski T., Collen B., McRae L., Loh J., Grillas P., Gauthier-Clerc M. \& Devictor V., 2011 - Long-term trends in the abundance of Mediterranean wetland vertebrates: From global recovery to localized declines. Biological Conservation, 144: 1392-1399.

Green A. J., El Hamzaoui M., El Agbani M. A. \& Franchimont J., 2002 - The conservation status of Moroccan wetlands with particular reference to waterbirds and to changes since 1978. Biological Conservation, 104: 71-82.

Hoffmann L., Hafner H. \& Tobias Salathé T., 1996 - The Contribution of Colonial Waterbird Research to Wetland Conservation in the Mediterranean Region. Colonial Waterbirds, 19, Special Publication 1: Ecology, Conservation, and Management of Colonial Waterbirds in the Mediterranean Region, Waterbird Society: 12-30.

Magurran A., 2004 - Measuring biological diversity. Blackwell, London.

Malavasi R., Battisti C. \& Carpaneto G. M., 2006 - Distribuzione spaziale dell'avifauna nidificante in relazione alle tipologie di uso/copertura del suolo. In: Biodiversità, gestione, conservazione di un'area umida del 
litorale tirrenico: La Palude di Torre Flavia. Battisti C. (ed.). Provincia di Roma, Gangemi editore, Roma: 316-324.

Malcolm J. R., Liu C., Neilson R. P., Hansen L. \& Hannah L., 2006 - Global warming and extinctions of endemic species from biodiversity hotspots. Conservation Biology, 20: 538-548.

Massa B. \& La Mantia T., 2010 - The decline of groundnesting birds in the agrarian landscape of Italy. Revue d'Écologie - La Terre et la Vie, 65: 73-90.

Mediterranean Wetlands Observatory, 2012 - First Mediterranean Wetlands Observatory report. Technical report, 2012. Tour du Valat, France.

Mediterranean Wetlands Observatory, 2018 - Solutions for sustainable Mediterranean Wetlands, 2018. Tour $d u$ Valat, France.

Mitsch W. J., Bernal B., Maria E. \& Hernandez M. E., 2015 - Ecosystem services of wetlands. International Journal of Biodiversity Science, Ecosystem Services \& Management, 11: 1-4.

Okruszko T., Duel H., Acreman M., Grygoruk M., Flörke M. \& Schneider C., 2011 - Broad-scale ecosystem services of European wetlands-overview of the current situation and future perspectives under different climate and water management scenarios. Hydrological Sciences Journal, 56 (8): 1501-1517.

Ortega M., Velasco J., Millán A. \& Guerrero C., 2004 An ecological integrity index for littoral wetlands in agricultural catchments of semiarid Mediterranean regions. Environmental Management, 33: 412-430.

Perennou C., Beltrame C., Guelmami A., Tomas Vives P. \& Caessteker P., 2012 - Existing areas and past changes of wetland extent in the Mediterranean region: an overview. Ecologia Mediterranea, 38: 53-66.

Robledano F., Esteve M. A., Farinòs P., Carreno M. F. \& Martınez-Fernandez J., 2010 - Terrestrial birds as indicators of agricultural-induced changes and associated loss in conservation value of Mediterranean wetlands. Ecological Indicators, 10: 274-286.

Sanderson F. J., Donald P. F., Pain D. J., Burfield I. J. \& Van Bommel F. P., 2006 - Long-term population declines in Afro-Palearctic migrant birds. Biological Conservation, 131: 93-105.

Sutherland W. J. (ed.), 2006 - Ecological census techniques: a handbook. Cambridge University Press, Cambridge.

Tomaselli R., Balduzzi A. \& Filippello S., 1973 -Carta Bioclimatica d'Italia. Ministero Agricoltura e Foreste, Roma, Collana verde, 33.

Zalidis G., Takavakoglou V. \& Gerakis A., 1999 - Wetland rehabilitation in the Mediterranean basin. An international perspective on wetland rehabilitation. Springer, Dordrecht: 55-68. 